\title{
Evaluation Of The Potential Mutagenic Effects Of Ginseng On Maternally Treated Postimplanted Mouse Foetuses
}

\author{
H.M. El Ashmaoui, S. M. Girgis and Abd El Raouf, A. \\ Cell Biology Department, National Research Centre, 12622 - Dokki, Cairo, Egypt
}

\begin{abstract}
The aim of this study was to evaluate the potential mutagenic effects of ginseng (herbal medicine) on maternally treated postimplanted mouse foetuses. A total of 60 adult albino female mice were used and divided into 6 groups (10 females each). The first group (I) served as a control group and received oral doses of the vehicle $(0.5 \mathrm{ml}$ disteled water $)$ for 60 days before pregnancy to $13^{\text {th }}$ day of pregnancy. The rest 5 groups received orally $4 \mathrm{mg} / \mathrm{kg}$.bw of ginseng for $7,14,30,45$ and 60 days before day 0 of gestation and extended to $13^{\text {th }}$ day of pregnancy. Then 6 females of each group were sacrificed, feotuses sample from each female were taken and subjected to cytogenetic analysis. The rest females of each group (4 females) were continuously treated and sacrificed at day 17 of getation, foetuses were examined morphologically and for different features such as implanation sites, living feotuses, resorbed foetuses and foetus body weight. Chromosome analysis of the present study (Table 1) revealed that there were numerical aberrations (peridiploidy). There was a difference only between group II and III in respect to hypodiploid (2n-), meanwhile, hyperdiploid $(2 n+)$ were more frequent in group IV and VI than that in control group (group I). For the total numerical aberrations, there were significant differences between groups II, VI compared to the control group. All groups had little frequencies of structural aberrations especially for chromatid gaps, breaks and fragments. There were a significant differences between group IV and VI compared with the control group for the deletions. Chromosome breaks were more frequent in the groups III and IV compared to the control group, whereas groups V, VI had more frequencies of centromeric attenuations than the control group. There were no differences between control group and the rest of all groups investigated for implantation sites, living foetuses and resorbed foetuses (Table 2), whereas for gross malformation, $5.41 \%$ of group VI where abnormal and the rest of all groups had no malformations. For the mean fetal body weight, there was a significant difference among the control group (I) and the groups number II, III and VI. We conclude that treatment with ginseng as a herbal medicine may cause fetal chromosomal aberrations as well as gross malformation especially when taken for a long time and extended during pregnancy. So, we recommend that the use of ginseng during first trimester of pregnancy should be with caution.
\end{abstract}

Key words: Panax ginseng, mutagenicity, maternally treated, foetus, chromosomal aberration, mice.

\section{Introduction}

Ginseng (Panax ginseng) is a commonly used herbal medicine world-wide (one meant to be taken regularly that has cumulative strengthening effects). There are several varieties of ginseng. The three Panax species commonly used in herbal medicine are: 1) $P$. ginseng, grown in northeastern China and Korea; 2) P.quinquefolius, grown in the United States and Canada; and 3) P. notoginseng, grown in southwest China. Siberian ginseng is not ginseng at all, although it is in the same family (Araliaceae) and is also used for its tonic effects.

Ginseng contains ginsenosides (triterpene saponines); polyacetylenes (ginsenoynes A-K) and sesquiterpenes. Ginsenosides are believed to be major 
active agents of ginseng (Gillis, 1997). Ginsenoside can be divided into two major groups, namely Panaxadiol and Panaxatriol (Attele et al., 1999). Rb1 is the representative ginsenoside from the Panaxadiol group and the only one of the ginsenosides present in commercially available ginseng extracts.

In many countries, herbal medicine such as extracts of ginseng are placed on the market as food supplements. As a result , these food supplements are available over the counter and manufacturers are not required to submit proof of safety and efficacy before marketing. Although there are numerous reports in the literature concerning the potential beneficial effects of ginseng, much less is know about the potential toxicity or genotoxicity , previously reported potential adverse effects of ginseng include hypoglycemia , and increased risk of bleeding and decreased anticoagulant effect of warfarin (Ang - Lee et al., 2001). In fact as reported by De Smet (1995) many herbal medicines are associated with serious toxic effects (hepatotoxic, neurotoxic and teratogenic).

The findings of Rhee et al. (1990) revealed that the root extract of ginseng (0$1 \mu \mathrm{l} / \mathrm{ml}$ ) produced inhibitory effects on DNA synthesis, measured by thymidine incorporation into Chinese hamster lung cells. The results of tests for antimutagenic activity of ginseng are limited and somewhat contradictory. Oriental ginseng root, extracted in boiling water, didn't demonstrate antimutagenic activity or cytotoxicity in S.typhimurium strains TA 98 and TA 100; the mutagen was BAP and S-9 was prepared from PCB- induced rats (Sakai et al., 1988 and Rhee et al.,1990)

Despite widespread usage of ginseng during pregnancy, information concerning the potential mutagenic activity of ginseng or ginsenosides on developing foetus is lack. The study of Chan et al. (2003), revealed that ginsenoside $\mathrm{Rb} 1$ has a significant teratogenic and morphologic effects on rat embryos. Exposure to ginsenoside $\mathrm{Rb} 1$ at concentration of $\geq 30$ $\mu \mathrm{g} / \mathrm{ml}$ resulted in significant reduction of total morphological score and scores for some individual features. They concluded that the reduction in morphological scores for flaxion, forelimb and hindlimb are dose dependent. So it's recommended that the use of ginseng during first trimester of pregnancy should be with caution.

Coon and Ernst (2002) reported that the most commonly experienced adverse events with ginseng monopreparations are headache ,sleep and gastrointestinal disorders. The possibility of more serious adverse events is indicated in isolated case reports and data from spontaneous reporting schemes; however, causality is often difficult to determine from the evidence provided. Combination products containing ginseng as one of several constituents have been associated with serious adverse events and even fatalities .Interpretation of these cases is difficult as ingredients other than $P$. ginseng may have caused the problems. Possible drug interactions have been reported between $P$. ginseng and warfarin, phenelzine and alcohol. Collectively, these data suggest that $P$. ginseng monopreparations are rarely associated with adverse events or drug interactions.

In contrast Bespalov et al. (1993) reported that the drugs of ginseng could be used orally or intravaginally in mice during a long period of time of the postinitiation stage of carcinogenesis. All the drugs used locally effectively inhibited the development of induced carcinomas of uterus cervix and vagina. When orally used, the drugs of ginseng exhibited only an insignificant tendency to inhibit the carcinogenesis of uterus cervix and vagina.

There are numerous theories and claims describing the efficacy of ginseng, which can combat stress, enhance both the control and immune systems and contribute towards maintaining optimal oxidative status against certain chronic disease states and aging .

Risk issues concerning the safety of ginseng at recommended dosages are less prominent and scientifically based. While some epidemiological or clinical studies have reported indications of efficacy for specific health benefits or potential toxicity, there are an equal number of studies that provide contradictory evidence (Kitts and $\mathrm{Hu}, 2000)$. 
The aim of the present study was to evaluate the potential mutagenic effects of ginseng on maternally treated day 13 mouse foetuses through cytogenetic analysis. In addition the morphological scores of day 17 mouse foetuses were evaluated for gross malformation (abnormal foetuses ) and for other features such as implantation sites, living foetuses, resorbed foetuses and foetuses body weight.

\section{Materials and Methods}

Inbred normal albino-female mice, 810 weeks old and weighing 25.8-30.2g were used in the present study. Animals were kept and bred under controlled room. Rodent chow commercially and water were offered ad-libitum.

In each box, 4-5 nulliparous females were caged together with a single male. The day the plug was detected was considered as day 0 of gestation and the pregnant females were placed in separate cages. A total of 60 pregnant females were used and received same dose (4 mg/kg.bw) of ginseng (Pharco Pharmaceuticals, Alexandria, Egypt) and were divided into 6 groups (I to VI), 10 females each.

The females of group II, III, IV, V and VI were treated for 7, 14, 30, 45 and 60 days, respectively before day 0 of gestation up to day 13 of pregnancy with a daily single oral dose of $4 \mathrm{mg} / \mathrm{kg}$.bw/day calculated according to Paget and Barnes (1964).

Group I pregnant females served as a control group and received oral doses of the vehicle $(0.5 \mathrm{ml}$ disteled water) 60 days before pregnancy to day 13 of pregnancy. At $13^{\text {th }}$ day of gestation, females were sacrificed by cervical dislocation, foetuses from each female were removed randomally, foetuses sample were taken from each female at each group to investigate the cytogenetic effect of ginseng according to the method of Romagnano et al. (1985).

The slides were examined for metaphase stage (50 metaphase spreads for each foetus were analyzed). The rest females for each group (4 females) were continuously treated and sacrificed at $17^{\text {th }}$ day of gestation by cervical dislocation, then the abdominal wall was opened and the uterine horns were then opened and the live foetuses was determined and examined for gross malformation under a stereoscopic microscope.

\section{Statistical analysis :}

Data are expressed as means \pm SE and were subjected to Fisher's analysis of variance (ANOVA) using a Statistical Package for Social Sciences (SPSS), and the results were compared by Duncan's Multiple Range Test. Significance level was $\mathrm{P} \leq 0.05$.

\section{Results and Discussion}

After the treatment of five groups of mice female with ginseng for different periods before gestation $(7,14,30,45$ and 60 days ,respectively ) up to $13^{\text {th }}$ day of pregnancy, beside the control group. Table 1 summarizes cytogenetic analysis of day 13 mouse foetuses based on both numerical and structural chromosomal aberrations for each group under study.

\section{Numerical aberrations :}

Chromosome analysis in the present study showed that there were numerical aberrations (peridiploidy). Peridiploidy included cells with lack (2n-) or excess $(2 n+)$ of single chromosomes, concerning the lack of single chromosomes, there was a difference only between group II and III. The excess of single chromosomes (41 and 42 chromosomes) were more frequent in group IV and VI than that in control group (group I). Statistical analysis revealed that there were significant differences between groups II ,VI compared to the control group for the frequencies of total numerical aberrations.

\section{Structural aberrations:}

Structural aberrations observed in our work consisted of deletions (Fig.2a), chromatid and chromosome gaps (Fig.2b), chromatid (Fig.2b) and chromosome breaks(Fig.2c), centomeric attenuations (Fig.2d) and fragments(Fig.2a). The results indicated that all groups had little chromosome aberrations especially for chromatid gaps, breaks and fragments, 
where the only difference for the chromatid gaps was between the group II and the control group. For the chromatid breaks the difference was between groups III and V.

There were a significant differences between group IV and VI compared with the control group for the deletions from one side and between groups III and V compared with group VI, on the other side. Chromosome breaks were more frequent in the groups III and IV compared to the control group, whereas groups $\mathrm{V}$, VI had more frequencies of centromeric attenuations than the control group.

\section{Mutagenic evaluation of ginseng:}

Mutagenic effects of ginseng was evaluated upon day 17 mouse foetuses for implantation sites, living foetuses, foetus body weight, resorbed foetuses and gross malformation (abnormality). The results of the present study showed that there were no differences between control group and the rest of all groups investigated for implantation sites, living feotuses and resorbed foetuses (Table 2 and Fig.3), whereas for gross malformation (abnormal foetuses), it was found that $5.41 \%$ of group VI where abnormal (Table 2), and there were no abnormalities in the rest of all groups checked for gross malformation.

There was a significant difference among the control group and the groups number II, III and VI in respect to mean fetal body weight, which were $0.88 \pm 0.006$, $0.85 \pm 0.01,0.85 \pm 0.008$ and $0.80 \pm 0.007$ gm for the control (I), II, III and VI groups, respectively.

The mutagenicity of ginseng was clearly appeared only by the long period treatment which started from 60 days before gestation up to the $17^{\text {th }}$ day of pregnancy. The percent of foetuses malformation reached to $5.41 \%$ in the form of abnormal hindlimb. That coincide with the findings of Chan et al. ( 2003) which revealed that ginsenosides (the major active agents of ginseng) had a significant teratogenic and morphologic effects on rat embryos especially when the dose concentration was $\geq 30 \mu \mathrm{g} / \mathrm{ml}$ and that resulted in a significant reduction of total morphological score and scores for some individual features. In addition De Smet (1995) reported that many herbal medicines have a teratogenic effects.

In contrast Coon and Ernst (2002) reported that most commonly experienced adverse events with ginseng are headache, sleep and gastrointestinal disorders and concluded that $P$. ginseng monopreparations are rarely associated with adverse events or drug interaction.

On another hand, the studies of Kitts and $\mathrm{Hu}$ (2000) showed that efficacy and safety of ginseng which can combat stress, enhance both the central and immune systems and contribute towards maintaining optimal oxidative status against certain chronic disease states and aging.

\section{Effect of ginseng on average fetal body weights:}

The values of mean fetal body weight after maternal treatment with ginseng reflect the embryotoxic influence of ginseng, where a small but significant decrease in fetal body weights was found on $17^{\text {th }}$ day of gestation among the control group (I) and groups II,III and VI (Table 2 indicated that the mean fetal body weight were $0.88 \pm 0.006,0.85 \pm 0.01,0.85 \pm$ 0.008 and $0.80 \pm 0.007 \mathrm{gm}$ for the control (I), II, III and VI groups, respectively).

In conclusion, the results of this study revealed that treatment with ginseng as a herbal medicine may cause embryonic chromosomal aberrations as well as gross malformation especially when taken for a long time and extended during pregnancy. Even some theories and claims describing the efficacy and safety of ginseng, which can combat stress, enhance both the central and immune systems and contribute towards maintaining optimal oxidative status against certain chronic diseases and aging, the use of ginseng during first trimester of pregnancy should be with caution. 
Table (1): Mean values of chromosomal aberrations induced by ginseng maternally treated $13^{\text {th }}$ day mouse foetuses

\begin{tabular}{|c|c|c|c|c|c|c|c|c|c|c|c|}
\hline $\begin{array}{l}\text { Treatment } \\
\text { periods } \\
\text { (days) }\end{array}$ & $\begin{array}{l}\text { Hypodiploid } \\
(2 n-) \\
\text { Mean } \pm \text { SE }\end{array}$ & $\begin{array}{c}\text { Hyperdiploid } \\
(2 n+) \\
\text { Mean } \pm \text { SE }\end{array}$ & $\begin{array}{c}\text { Total } \\
\text { numerical } \\
\text { aberrations } \\
\text { Mean } \pm \text { SE }\end{array}$ & $\begin{array}{c}\text { Deletions } \\
\text { Mean } \pm \text { SE }\end{array}$ & $\begin{array}{c}\text { Chromatid } \\
\text { gaps } \\
\text { Mean } \pm \text { SE }\end{array}$ & $\begin{array}{c}\text { Chromosome } \\
\text { gaps } \\
\text { Mean } \pm \text { SE }\end{array}$ & $\begin{array}{c}\text { Chromatid } \\
\text { breaks } \\
\text { Mean } \pm \text { SE }\end{array}$ & $\begin{array}{l}\text { Chromosome } \\
\text { breaks } \\
\text { Mean } \pm \text { SE }\end{array}$ & $\begin{array}{l}\text { Centromeric } \\
\text { attenuation } \\
\text { Mean } \pm \text { SE }\end{array}$ & $\begin{array}{l}\text { Fragments } \\
\text { Mean } \pm \text { SE }\end{array}$ & $\begin{array}{c}\text { Total } \\
\text { structural } \\
\text { aberrations } \\
\text { Mean } \pm \text { SE }\end{array}$ \\
\hline GI (control) & $\begin{array}{l}1.00 \pm \\
0.22^{\mathrm{ab}}\end{array}$ & $\begin{array}{l}0.50 \pm \\
0.00^{\mathrm{b}}\end{array}$ & $\begin{array}{l}1.50 \pm \\
0.22^{\mathrm{b}}\end{array}$ & $1.00 \pm 0.34^{\mathrm{c}}$ & $\begin{array}{l}3.17 \pm \\
0.42^{\mathrm{a}}\end{array}$ & $\begin{array}{l}1.00 \pm \\
0.22^{\mathrm{bc}}\end{array}$ & $\begin{array}{l}1.67 \pm \\
0.17^{\mathrm{ab}}\end{array}$ & $0.50 \pm 0.00^{c}$ & $1.33 \pm 0.31^{c}$ & $2.17 \pm 0.21^{a}$ & $10.83 \pm 0.71^{b}$ \\
\hline GII (7 days) & $\begin{array}{l}1.83 \pm \\
0.49^{\mathrm{a}}\end{array}$ & $\begin{array}{l}0.67 \pm \\
0.17^{\mathrm{ab}}\end{array}$ & $\begin{array}{l}2.50 \pm \\
0.50^{\mathrm{a}}\end{array}$ & $\begin{array}{c}1.67 \pm \\
0.31^{\mathrm{abc}}\end{array}$ & $\begin{array}{l}1.500 \\
\pm 0.37^{b}\end{array}$ & $0.67 \pm 0.17^{c}$ & $\begin{array}{l}2.67 \pm \\
0.48^{\mathrm{ab}}\end{array}$ & $1.33+0.31^{\mathrm{dx}}$ & $1.83 \pm 0.33^{b c}$ & $1.33 \pm 0.31^{\mathrm{a}}$ & $9.50 \pm 1.90^{b}$ \\
\hline $\begin{array}{l}\text { GIII (14 } \\
\text { days) }\end{array}$ & $\begin{array}{l}0.83 \pm \\
0.21^{b}\end{array}$ & $\begin{array}{l}0.67 \pm \\
0.17^{\mathrm{ab}}\end{array}$ & $\begin{array}{l}1.50 \pm \\
0.22^{\mathrm{b}}\end{array}$ & $\begin{array}{l}1.17 \pm \\
0.21^{\mathrm{bc}}\end{array}$ & $\begin{array}{l}2.50 \pm \\
0.45^{\mathrm{ab}}\end{array}$ & $\begin{array}{l}1.50 \pm \\
0.26^{\mathrm{ab}}\end{array}$ & $\begin{array}{l}1.50 \pm \\
0.52^{\mathrm{b}}\end{array}$ & $1.50 \pm 0.37^{\text {कb }}$ & $1.00 \pm 0.34^{c}$ & $1.50 \pm 0.52^{\mathrm{a}}$ & $10.67 \pm 1.30^{b}$ \\
\hline $\begin{array}{l}\text { GIV (30 } \\
\text { days) }\end{array}$ & $\begin{array}{l}1.33 \mathrm{t} \\
0.31^{\mathrm{ab}}\end{array}$ & $\begin{array}{l}0.50 \pm \\
0.00^{\frac{t}{b}}\end{array}$ & $\begin{array}{l}1.83 \pm \\
0.31^{\mathrm{ab}}\end{array}$ & $\begin{array}{l}2.17 \pm \\
0.42^{\mathrm{ab}}\end{array}$ & $\begin{array}{l}2.33 \pm \\
0.40^{\mathrm{ab}}\end{array}$ & $\begin{array}{l}2.00 \pm \\
0.34^{\mathrm{a}}\end{array}$ & $1.67 \pm 0.31^{\mathrm{ab}}$ & $1.67 \pm 0.40^{\mathrm{a}}$ & $1.00 \pm 0.34^{c}$ & $2.00 \pm 0.43^{\mathrm{a}}$ & $12.83 \pm 0.71^{a b}$ \\
\hline $\begin{array}{l}\text { GV }(45 \\
\text { days) }\end{array}$ & $\begin{array}{l}1.50 \pm \\
0.26^{\mathrm{ab}}\end{array}$ & $\begin{array}{c}0.67 \\
\pm 0.17^{\mathrm{ab}}\end{array}$ & $\begin{array}{l}2.17 \pm \frac{ \pm}{a b} \\
0.17^{\mathrm{b}}\end{array}$ & $0.67 \pm 0.17^{c}$ & $\begin{array}{l}2.83 \pm \frac{t}{\mathrm{ab}} \\
0.42^{\mathrm{b}}\end{array}$ & $0.67 \pm 0.17^{\mathrm{c}}$ & $\begin{array}{l}2.83 \pm \\
0.42^{\mathrm{a}}\end{array}$ & $0.67 \pm 0.17^{6 x}$ & $2.83 \pm 0.49^{\text {b }}$ & $2.00 \pm 0.43^{\mathrm{a}}$ & $12.50 \pm 0.89^{2 b}$ \\
\hline $\begin{array}{c}\text { GVI (60 } \\
\text { days) }\end{array}$ & $\begin{array}{l}1.50 \pm \\
0.26^{\mathrm{ab}}\end{array}$ & $\begin{array}{l}1.00 \pm \\
0.22^{\mathrm{a}}\end{array}$ & $\begin{array}{l}2.50 \pm \\
0.22^{\mathrm{a}}\end{array}$ & $\begin{array}{l}2.33 \pm \\
0.48^{\mathrm{a}}\end{array}$ & $\begin{array}{l}2.50 \pm \frac{t}{2} \\
0.52^{\mathrm{ab}}\end{array}$ & $\begin{array}{l}1.17 \pm \pm \\
0.21^{\mathrm{bc}}\end{array}$ & $2.67 \pm 0.31^{\mathrm{ab}}$ & $0.67 \pm 0.17^{\text {b }}$ & $3.50 \pm 0.73^{\mathrm{a}}$ & $2.00 \pm 0.34^{a}$ & $14.83 \pm 0.67^{\mathrm{a}}$ \\
\hline
\end{tabular}

Mean with different superscript letters are significantly different $(\mathrm{P} \leq 0.05)$.

$\mathrm{SE}=$ standard error.

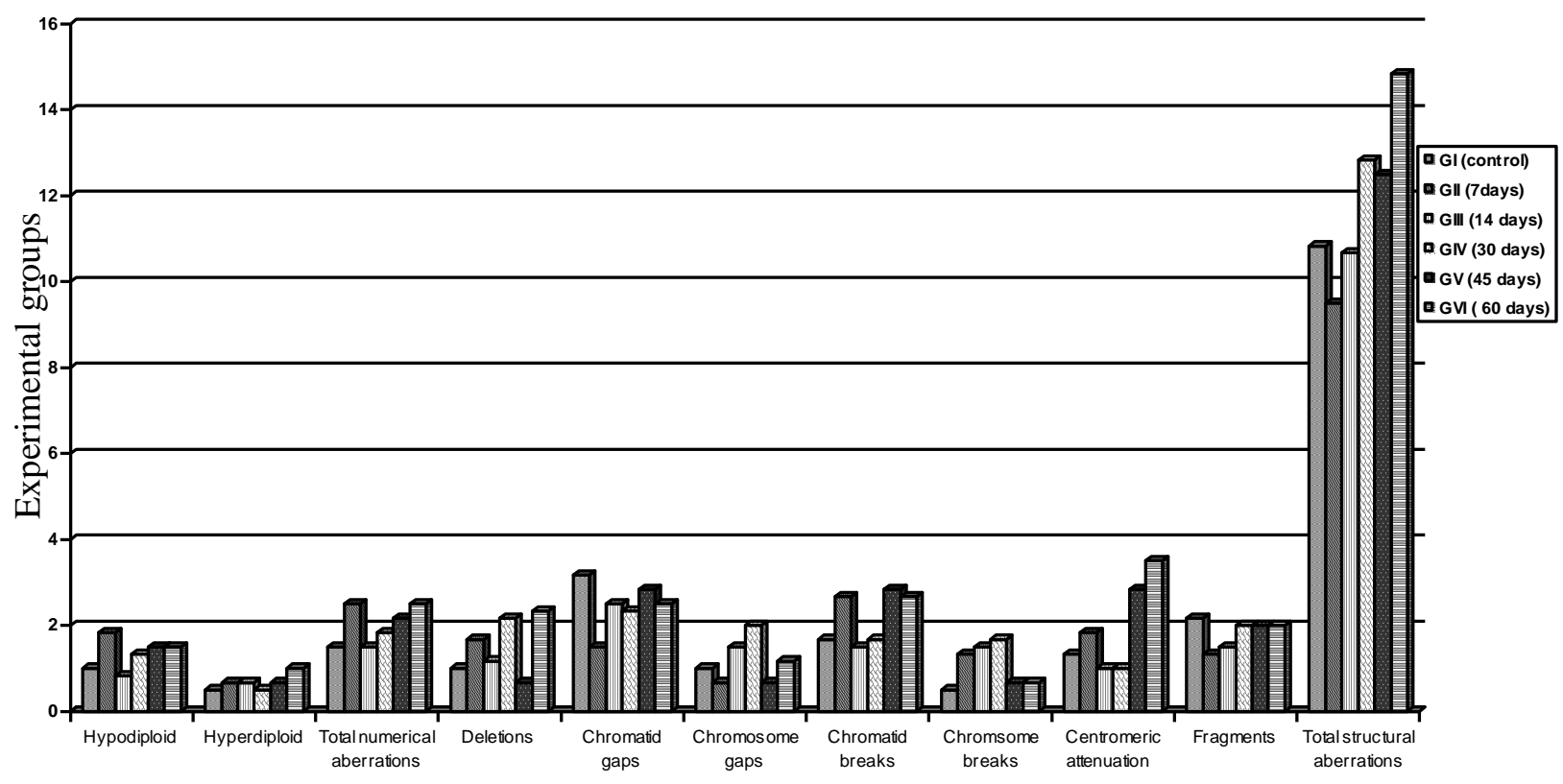

\section{Chromosomal aberrations}

Fig. (1): Histogram shows the mean values of chromosomal aberrations induced by ginseng in maternally treated $13^{\text {th }}$ day mouse foetuses. 

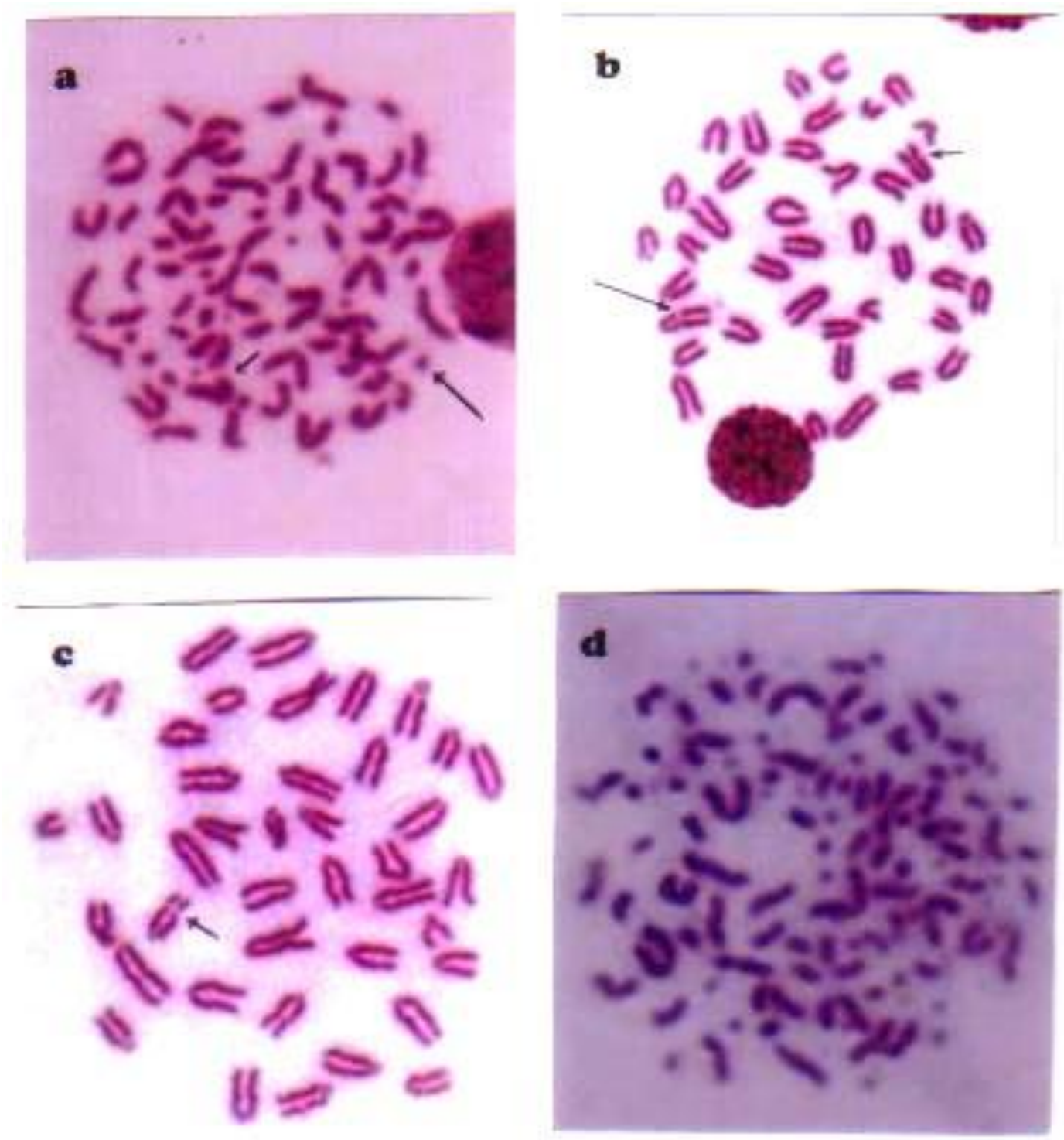

Fig (2): Metaphase spreads from ginseng maternally treated $13^{\text {th }}$ day mouse foetuses showing : a) deletion (small arrow), fragment (large arrow). b) chromosome gap (small arrow), chromatid break (large arrow). c) chromosome break. d) centromeric atttenuation. (Giemsa stain, $X$ 1000) 
Table (2): Mean values of different features of ginseng maternally treated $17^{\text {th }}$ day mouse foetuses.

\begin{tabular}{|c|c|c|c|c|c|}
\hline $\begin{array}{l}\text { Treatment } \\
\text { periods (days) }\end{array}$ & $\begin{array}{l}\text { Implantation } \\
\text { sites } \\
\text { Mean } \pm \text { SE }\end{array}$ & $\begin{array}{l}\text { Living } \\
\text { foetuses } \\
\text { Mean } \pm \text { SE }\end{array}$ & $\begin{array}{l}\text { Resorbed } \\
\text { foetuses } \\
\text { Mean } \pm \text { SE }\end{array}$ & $\begin{array}{l}\text { Foetus body } \\
\text { weight (gm) } \\
\text { Mean } \pm \text { SE }\end{array}$ & $\begin{array}{l}\text { Abnormal } \\
\text { foetuses } \\
(\%)\end{array}$ \\
\hline GI (control) & $11.50 \pm 0.41^{\mathrm{a}}$ & $\begin{array}{ll}11.00 & \pm \\
0.29^{\mathrm{a}} & \end{array}$ & $1.00 \pm 0.29^{\mathrm{a}}$ & $0.88 \pm 0.006^{\mathrm{a}}$ & 0.00 \\
\hline GII (7 days) & $10.75 \pm 0.48^{\mathrm{a}}$ & $\begin{array}{ll}10.25 & \pm \\
0.63^{\mathrm{a}} & \end{array}$ & $1.00 \pm 0.29^{\mathrm{a}}$ & $0.85 \pm 0.01^{b}$ & 0.00 \\
\hline GIII (14 days) & $10.50 \pm 0.71^{\mathrm{a}}$ & $\begin{array}{l}10.25 \\
0.48^{\mathrm{a}} \\
\end{array}$ & $0.75 \pm 0.25^{\mathrm{a}}$ & $\begin{array}{ll}0.85 & \pm \\
0.008^{\mathrm{b}} & \end{array}$ & 0.00 \\
\hline GIV (30 days) & $10.75 \pm 0.85^{\mathrm{a}}$ & $\begin{array}{l}10.00 \\
0.65^{\mathrm{a}}\end{array}$ & $1.25 \pm 0.48^{\mathrm{a}}$ & $0.89 \pm 0.007^{\mathrm{a}}$ & 0.00 \\
\hline GV (45 days) & $10.25 \pm 0.48^{\mathrm{a}}$ & $\begin{array}{l}10.00 \\
0.65^{\mathrm{a}}\end{array}$ & $0.75 \pm 0.25^{\mathrm{a}}$ & $0.89 \pm 0.006^{\mathrm{a}}$ & 0.00 \\
\hline GVI (60 days) & $11.00 \pm 0.65^{\mathrm{a}}$ & $9.75 \pm 0.85^{\mathrm{a}}$ & $1.50 \pm 0.58^{\mathrm{a}}$ & $0.80 \pm 0.007^{\mathrm{c}}$ & 5.41 \\
\hline
\end{tabular}

a-c significance $(\mathrm{P} \leq 0.01)$ was determined using one way analysis of variance (ANOVA)

Within a column, values with no common superscript are significantly different.

Abnormal foetuses column represented as a percent.

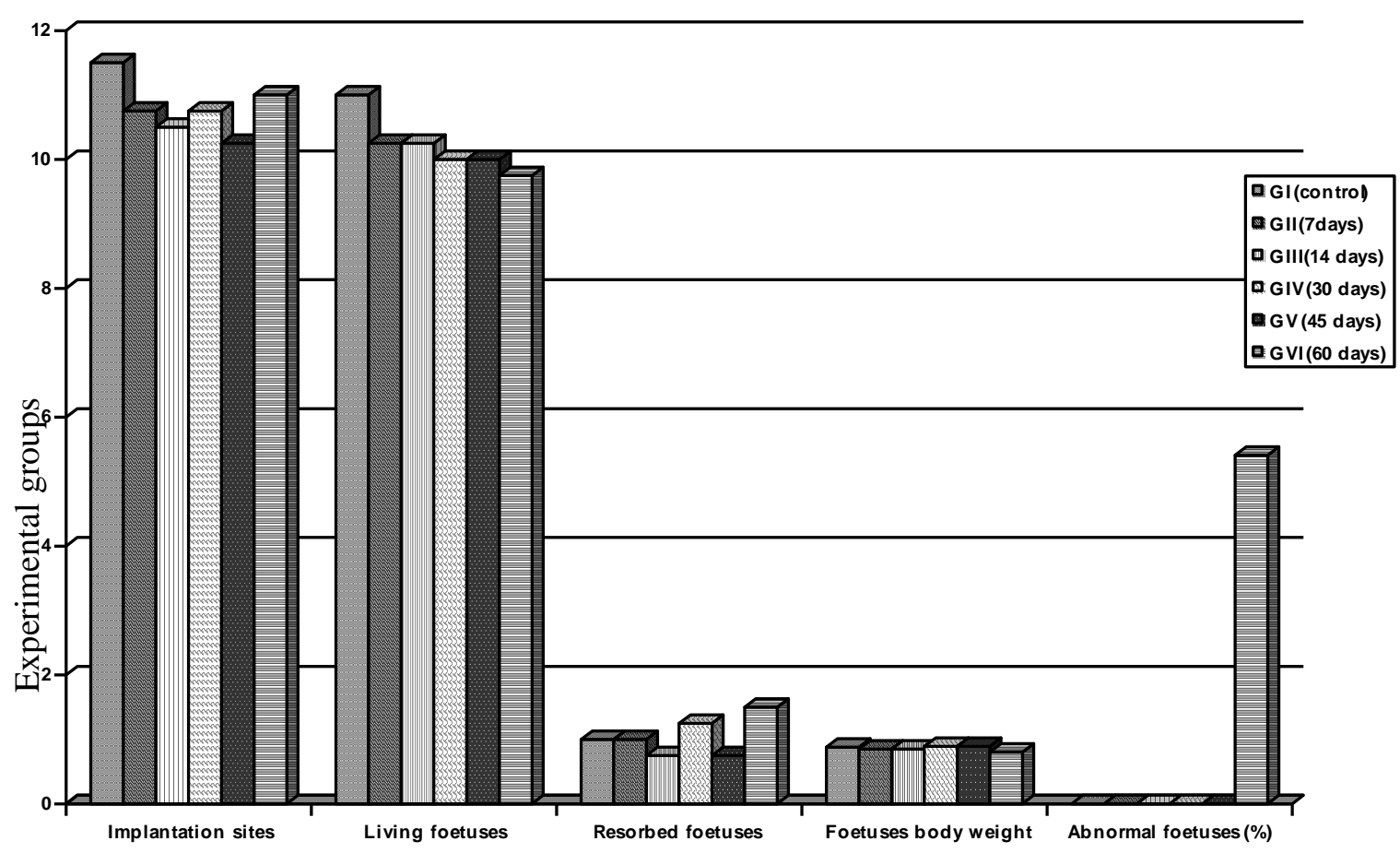

Fig. (3): Histogram shows the mean values of different features of ginseng maternally treated $17^{\text {th }}$ day mouse foetuses. N.B: Abnormal foetuses column represented as a percent. 


\section{References}

1. Ang - Lee, M.K.; Moss, J. and Yuan, C.S. (2001): Herbal medicines and perioperative care. JAMA., 286: 208-216.

2. Attele, A.S.; Wu, J.A.; Yuan, C.S. (1999): Ginseng Pharmacology: multiple constituents and multiple actions. Biochem. Pharmacol., 58 (11): 1685-1693.

3. Bespalov, V.G.; Davydov, V.V.; Limarenko AIU, Slepian L.I. and Aleksandrov, V.A. (1993): The inhibition of the development of experimental tumors of the cervix uteri and vagina by using tinctures of the cultured-cell biomass of the ginseng root and its germanium-selective stocks. Bulk Eksp Biol Med., 116 (11): 534-6.

4. Chan, L.Y.; Chiu, P.Y. and Lau, T.K. (2003): An in-vitro study of ginsenoside Rb1- induced teratogenicity using a whole rat embryo culture model. Hum. Reprod., 18 (10): 2166-2168.

5. Coon, J.T. and Ernst, E. (2002): Panax ginseng: a systematic review of adverse effects and drug interactions. Drug Saf., 25 (5): 323-44.

6. De Smet, P.A. G.M. (1995): Health risks of herbal remedies. Drug Saf., 13; 81-93.
7. Gillis, C.N. (1997): Panax ginseng pharmacology: a nitric oxide link? Biochem. Pharmacol., 54: 1-8.

8. Kitts, D. and Hu, C. (2000): Efficacy and safety of ginseng. Public Health Nutr., 3 (4A): 473-85.

9. Paget, G.E. and Barnes, J.M. (1964): Evaluation of drug activities. In : Pharmacometrics $1^{\text {st }}$ ed. Laurence, Acad. Press, London and New York.

10. Rhee, Y.H.; Ahn, J.H.; Choe, J.; Kang, K.W. and Joe, C. (1990): Inhibition of mutagenesis and transformation by root extracts of Panax ginseng in vitro. Planta Med., 57 (2): 125-128.

11. Romagnano, A.; King, A.W.; Richer, C.L. and Perrone, M.A. (1985): A direct technique for the preparation of chromosomes from early equine embryos. J. Genet. Cytol., 27: 365-369.

12. Sakai, Y.; Nagase, H.; Ose, Y.; Sato, T.; Kawai, M. and Mizuno, M. (1988): Effects of medicinal plant extracts from Chinese herbal medicines on the mutagenic activity of benzo [a] pyrene. Mutat. Res., 206: 327-334. 


\section{تقييم التأثير الطفرى على اجنة الفئران بعد معاملة الأمهات بمادة الجنسينج

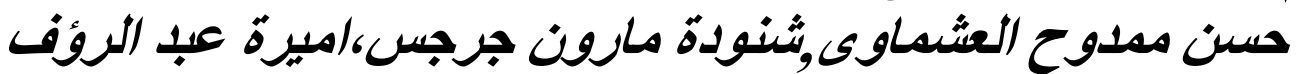 قسم بيولوجيا الخلية ـ المركز القومى للبحوث مارث ـ الدقى ـ القاهرة ـ مصر لروف}

تهدف هذه الدر اسـة إلى تقييم تأثير الجنسينج (عثب طبى) من حيث قدرنها علي إحداث

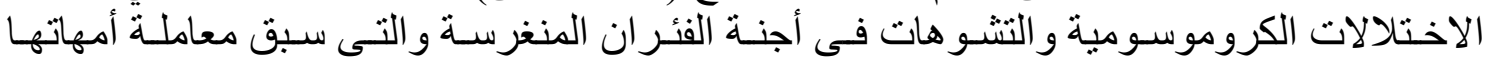

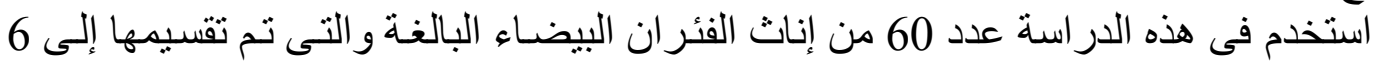
بالجنسينج. (- بلات

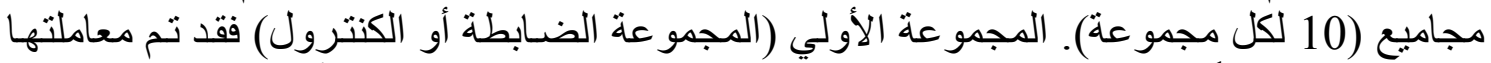

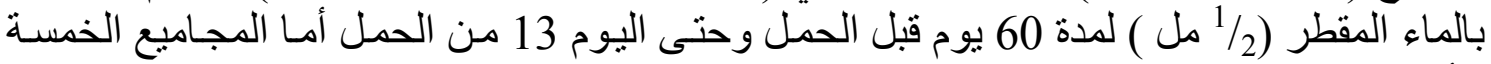

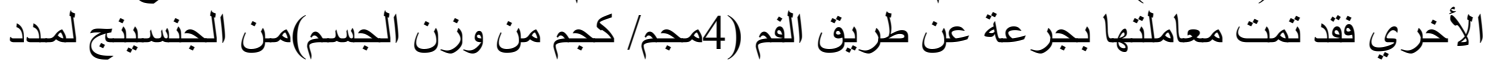

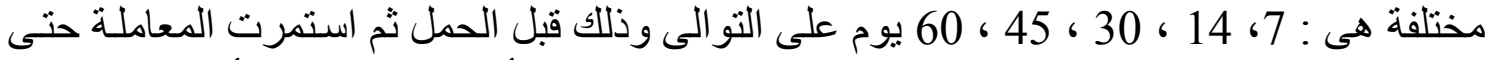

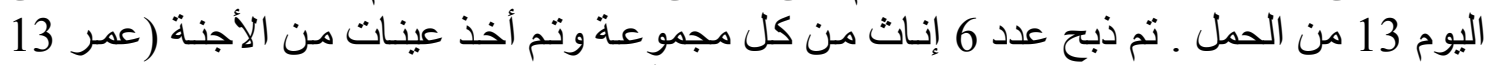

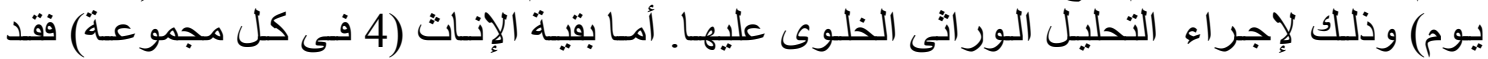

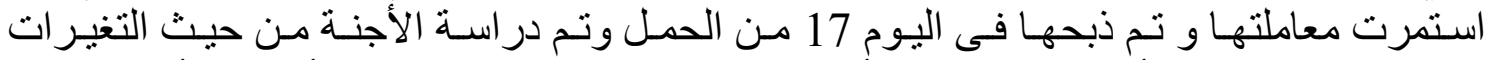

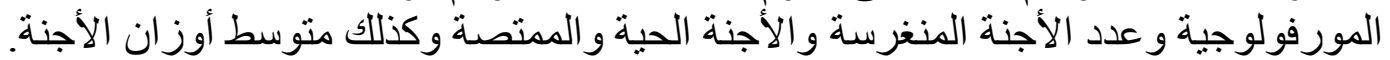

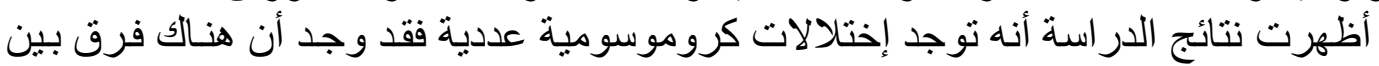

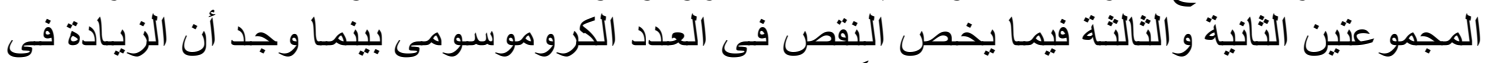

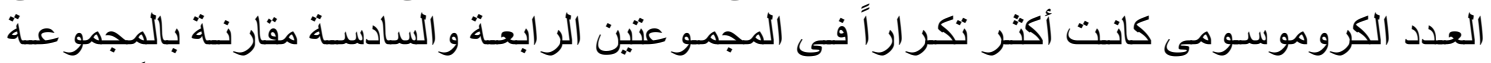

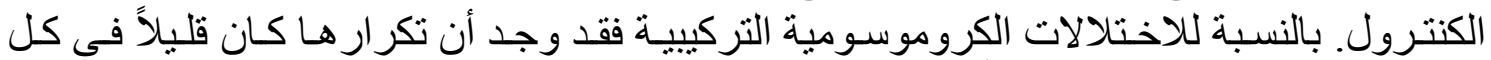

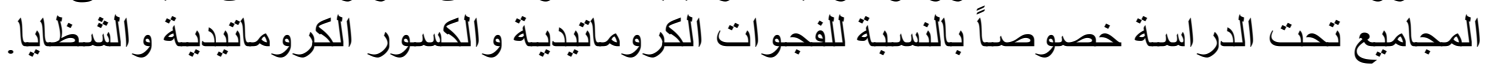

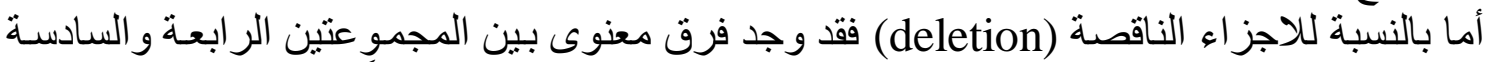

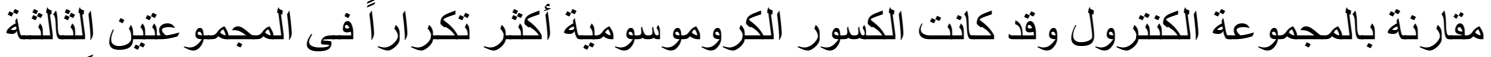

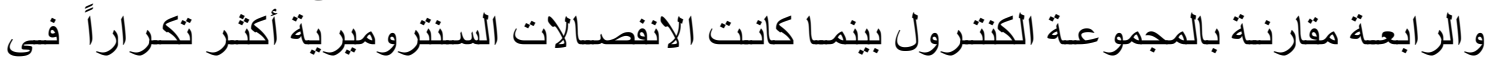

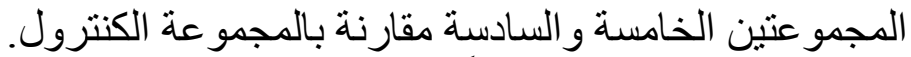

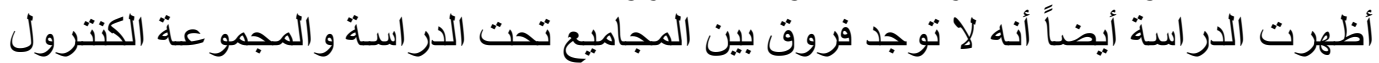

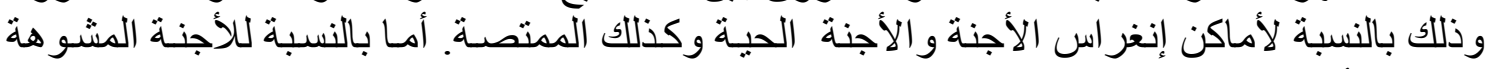

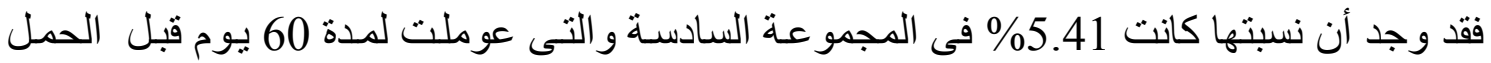

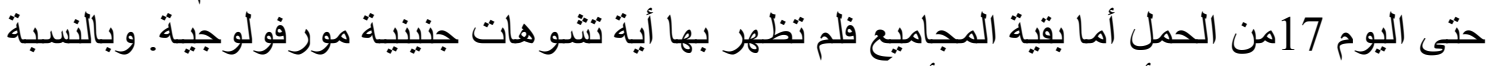

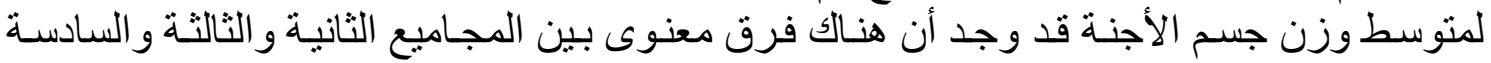

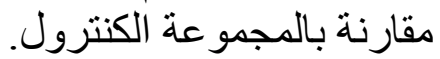

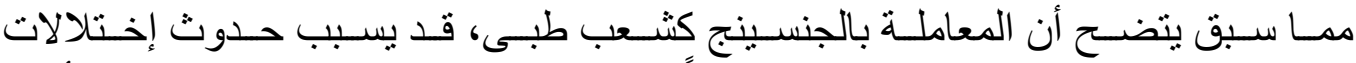

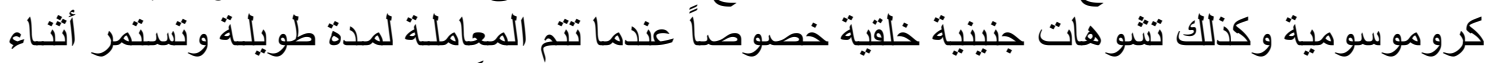

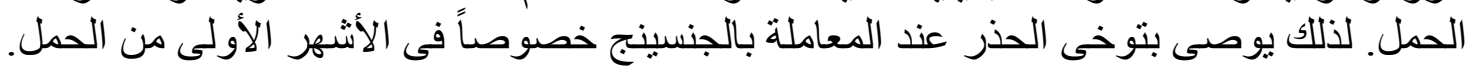

